YEARBOOK

of ANTITRUST

and REGULATORY

STUDIES

www.yars.wz.uw.edu.pl
Peer-reviewed scientific periodical, focusing on legal and economic issues of antitrust and regulation. Creative Commons Attribution-No Derivative Works 3.0 Poland License.

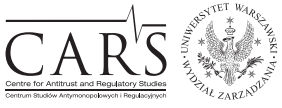

Centre for Antitrust and Regulatory Studies, University of Warsaw, Faculty of Management www.cars.wZ.uw.edu.pl

\title{
Competition Law in Western Balkans: Developments in 2018
}

\author{
by \\ Dragan Gajin*
}

\section{CONTENTS}
I. Introduction
II. Serbia
III. Montenegro
IV. Bosnia and Herzegovina
V. North Macedonia

\section{Abstract}

In 2018, the competition authorities in the Western Balkans (Serbia, Montenegro, Bosnia and Herzegovina, and North Macedonia) have continued with their enforcement activities. The level of their activity varies from year to year, but the trend has continued where the Serbian competition authority is the most active one in the region. Generally, the focus of the enforcement activities of the Balkan competition authorities is on merger control, an exception being Bosnia and Herzegovina, where the emphasis is on antitrust enforcement.

\section{Resumé}

En 2018, les autorités de concurrence des Balkans occidentaux (Serbie, Monténégro, Bosnie-Herzégovine et Macédoine du Nord) ont poursuivi leurs activités d'application du droit de la concurrence. Le niveau de leur activité varie d'une année à l'autre, mais la tendance s'est maintenue là où l'autorité serbe de la

* Dr. Dragan Gajin, a competition law expert and an attorney admitted in Serbia and New York. He is a Partner and Head of Competition at Doklestic Repic \& Gajin, a full-service law firm based in Belgrade, Serbia. He is also a Visiting Lecturer at the University of Szeged, Hungary; email: dragan@gajin.rs; blog: www.gajin.rs. Article received: 27 April 2019, accepted 1 June 2019. 
concurrence est la plus active dans la région. D’une manière générale, les activités d'application des règles menées par les autorités de concurrence des Balkans sont concentrées sur le contrôle des concentrations, à l'exception de la Bosnie-etHerzégovine, où l'accent est mis sur l'application des règles antitrust.

Key words: Western Balkans; Serbia; Montenegro; Bosnia and Herzegovina; North Macedonia; competition law; individual exemption; merger control; antitrust; restrictive agreements; abuse of dominance; enforcement.

JEL: K21

\section{Introduction}

The previous year was a busy one for the competition authorities in the Western Balkans (Serbia, Montenegro, Bosnia and Herzegovina, and North Macedonia). Across the region, the national competition authorities have had to deal with record numbers of merger filings. In addition, some of the jurisdictions in the region also had their hands full with respect to antitrust enforcement too - this is traditionally the case with Bosnia and Herzegovina and, in 2018, the Serbian competition authority must be singled out for its antitrust efforts as well.

Antitrust investigations against foreign-based entities, started by the Serbian competition authority, were a highlight of competition law enforcement in the Western Balkans in 2018. The Serbian competition authority launched three such cases, two being particularly significant - against MasterCard and Visa, respectively, concerning interchange fees. Will this bring more cross-border antitrust enforcement in this region?

Another highlight of competition law enforcement in the region in 2018 was the continuation of the 'ethnic veto' in the enforcement of competition law in Bosnia and Herzegovina. As will be described below, in its current form, Bosnian competition regulations effectively allow each of the three main ethnic groups in Bosnia and Herzegovina to veto a decision of the country's competition authority. It has been announced that this year we could see amendments to the country's competition legislation; will the 'ethnic veto' survive the planned amendments? 


\section{Serbia}

\section{Antitrust: several old cases closed, even more new opened}

During 2018, the Serbian national competition authority - Commission for Protection of Competition (hereinafter: Serbian NCA) - was quite active in the field of antitrust. Actually, the word 'hyperactive' would probably be more adequate to describe the level of the watchdog's enforcement activity. This was not reflected as much in the number of cases closed, as in the number of new cases the authority initiated.

Not counting the cases suspended through commitments, during 2018, the Serbian NCA closed four probes - one by terminating the investigation and three by finding an infringement. On the other hand, the number of newly opened cases was much higher. Specifically, in 2018 the Serbian NCA closed the following cases:

- Serbian Bar Association (terminated). The authority was not able to conclusively establish that the Serbian Bar Association concluded a restrictive agreement by the way it was setting the fees for the admission to the bar. As a result, the investigation was terminated. ${ }^{1}$

- Electric Power Industry of Serbia (finding of an infringement in a repeated proceeding). Back in 2016, the Serbian NCA had found that the electric power incumbent (EPS) had abused its dominance on the market. Eventually, this decision was quashed in court review and in a new decision the NCA repeated its earlier conclusion and imposed a fresh fine on EPS. ${ }^{2}$

- Price fixing (Škoda motor vehicles). The authority found that a Serbian importer of Škoda motor vehicles and several of its dealers had engaged in price fixing in public procurement (they agreed to fix the price which the dealers would offer in public procurement bids). The watchdog fined all undertakings involved. ${ }^{3}$

- Bid rigging (hygiene products). The authority established that four Serbian companies had colluded in order to fix the terms of their bids in the public procurement procedures organized by the Serbian Ministry of Defense. All parties received a fine. ${ }^{4}$

Apart from closing several investigations, the Serbian NCA also opened a number of new ones. When initiating new cases, the authority mostly

1 Conclusion of the Serbian NCA No. 4/0-02-101/2018-02 of 23 May 2018.

2 Resolution of the Serbian NCA No. 5/0-02-336/2018-30 of 18 June 2018.

3 Resolution of the Serbian NCA No. 4/0-02-64/2018-65 of 20 September 2018.

${ }^{4}$ Resolution of the Serbian NCA No. 4/0-02-61/2018-26 of 26 November 2018. 
focused on restrictive agreements, though there were a couple of new abuse of dominance probes too. These were the new restrictive agreement investigations:

- MasterCard (interchange fees). Perhaps the highlight of the Serbian NCA's enforcement in 2018 was the launch of an investigation against MasterCard, concerning the interchange fees applicable in Serbia. ${ }^{5}$ Eventually, MasterCard offered to the authority certain commitments in exchange for the suspension of the proceedings. At the time of the writing of this article, it is still not known whether the authority accepted these commitments.

- Visa (interchange fees). Not long after starting its probe against MasterCard, the Serbian NCA also went after Visa, with basically the same allegations as in the MasterCard case (that Visa was setting the interchange fees in Serbia in contravention of Serbian competition regulations). ${ }^{6}$ Visa too offered certain commitments to the NCA, the decision on which is pending.

- Polanik (sports equipment). Here, the Serbian NCA for the first time started an antitrust probe against a foreign-based entity (once the ice was broken, the authority also started a case against MasterCard and Visa, respectively). The case is still pending and involves a Polish company Polanik Sp. z o.o., active in the production and wholesale of sports equipment, and its Serbian distributor. The watchdog has alleged that their exclusive distribution agreement is not in accordance with Serbian competition law. ${ }^{7}$

- Baby equipment. The market for baby equipment seems to be on top of the Serbian NCA's list of priorities - apart from conducting a sector inquiry into this market, the authority has started proceedings against almost 200 undertakings dealing with baby products. So far, the watchdog is focusing on alleged RPM clauses in agreements between the market players in this sector.

- Bid rigging. Apart from baby equipment, another focus of the Serbian NCA is bid rigging. The authority has led several investigations with respect to this type of infringement and this continued in 2018. The watchdog has become more sophisticated when it comes to the assessment of possible bid rigging practices, as it now also discerns the existence of rigging from the patterns of behavior of the colluding parties. ${ }^{8}$

\footnotetext{
5 Conclusion of the Serbian NCA No. 4/0-02-640/2018-01 of 14 September 2018.

${ }^{6}$ Conclusion of the Serbian NCA No. 4/0-02-769/2018-01 of 2 November 2018.

7 Conclusion of the Serbian NCA No. 4/0-02-305/2018-1 of 28 March 2018.

8 See Conclusion of the Serbian NCA No. 4/0-02-673/2018-1 of 19 September 2018.
} 
- Price fixing (technical inspection of cars). The Serbian NCA is also investigating 11 undertakings active in the market for technical inspections of cars. The authority started the proceedings on suspicion that the undertakings had colluded with respect to the prices at which they offered their services, which may have amounted to a restrictive agreement within the meaning of Serbian competition law. ${ }^{9}$

- Non-compete (cinemas). In this case, the Serbian NCA is investigating whether a non-compete clause in an agreement between a cinema operator and an undertaking active in displaying cinematographic works through mobile cinema equipment may have led to a restriction of competition in the relevant market. ${ }^{10}$

In the field of abuse of dominance, the Serbian NCA started two new cases:

- Abusive pricing (Serbia Broadband). Back in 2017, the Serbian NCA conditionally approved Serbia Broadband's (SBB) takeover of a competing cable operator. One of the conditions under which the clearance was granted was SBB's obligation to inform the authority of any price hike and explain the reasons behind it. In early 2018, the operator increased the price of cable subscription and the watchdog has alleged this represented an act of abuse of dominance. ${ }^{11}$

- Abusive pricing (heating plant). The Serbian NCA has started an abuse of dominance probe against the company operating a heating plant in the city of Niš. Specifically, the NCA is investigating the company's pricing policy from an abuse of dominance perspective. ${ }^{12}$

\section{Commitments now regularly implemented in the authority's practice}

For a few years now, Serbian competition law has contained a commitments procedure comparable to the one found in Article 9 of Regulation 1/2003. Over time, the Serbian NCA has shown it is ready to implement this procedure in practice, a trend that continued in 2018.

Specifically, in 2018 the watchdog performed a market test of three commitment proposals submitted by undertakings under an antitrust investigation:

- Sirmiumbus, in an abuse of dominance case involving a bus station in a Serbian town; ${ }^{13}$

${ }^{9}$ See news article dated 26 December 2018, available on the website of the Serbian NCA at: http://www.kzk.gov.rs/en/pokrenut-postupak-zbog-sumnje-na-dogov (26.04.2019).

10 Conclusion of the Serbian NCA No. 4/0-02-786/2018-1 of 8 November 2018.

11 Conclusion of the Serbian NCA No. 5/0-02-297/2018-1 of 27 March 2018.

12 Conclusion of the Serbian NCA No. 5/0-02-459/2018-1 of 5 June 2018.

13 Notice of the Serbian NCA No. 5/0-02-52/2018-5 of 4 June 2018. 
- MasterCard, in an interchange fees case; ${ }^{14}$ and

- Visa, also in an interchange fees case. ${ }^{15}$

At the moment, it is known that the Serbian NCA has accepted the commitments proposed by Sirmiumbus and suspended the proceedings against this undertaking. It remains to be seen what conclusion the authority will reach concerning the commitments proposed by MasterCard and Visa, respectively.

\section{Individual exemptions continue}

Serbian competition law still has a system of individual exemptions of restrictive agreements based on an administrative decision of the Serbian NCA, comparable to the one which existed in the EU under Regulation 17/62. ${ }^{16}$ Under this procedure, the authority each year individually exempts around 20 agreements. However, it publishes only a small number of these decisions. For instance, during 2017, the NCA individually exempted 21 agreements but published just four exemption decisions.

During 2018, the Serbian NCA published three individual exemption decisions and at the moment we can only guess at the total number of such decisions. A more meaningful analysis of this segment of the authority's enforcement activities will be possible once the watchdog publishes its annual report for 2018, which is not yet available at the time of the writing of this article.

\section{Dawn raids: the constitutional challenge does not dent the authority's resolve}

The constitutionality of dawn raids in the Serbian legal system remains an unresolved issue, as the Serbian Constitutional Court is yet to rule on whether the current regulation of dawn raids in the Serbian Competition Act is constitutional. In any event, the Serbian NCA has continued to conduct dawn raids, despite the constitutional challenge.

Moreover, apart from raiding parties to the proceedings, the authority has also started performing dawn raids on the premises of third parties. Also, during the course of 2018, the authority published its official guidance on dawn raids, ${ }^{17}$ which allows undertakings to prepare in advance for what might await them in an unannounced inspection.

14 Notice of the Serbian NCA No. 4/0-02-640/2018-13 of 14 November 2018.

15 Notice of the Serbian NCA No. 4/0-02-769/2018-06 of 3 December 2018.

16 On this topic, see more in: Kojovic and Gajin, 2012.

17 Available on the website of the Serbian NCA at: http:/www.kzk.gov.rs/kzk/wp-content/ uploads/2018/05/Informacije_o_nenajavljenom_uvidjaju.pdf (26.04.2019). 


\section{Merger control: more than 150 new decisions}

Traditionally, the Serbian NCA is kept busy with merger control, due to the extremely low merger filing thresholds in Serbian competition law. As a result of such low merger filing thresholds, the number of merger decisions of the Serbian competition watchdog has quickly reached 1,000 . And the trend of proliferation of such decisions has continued in 2018.

While the exact number of merger decisions will be known with certainty only when the NCA publishes its official annual report, it is likely that 2018 will be a record year when it comes to the number of approved mergers. Specifically, during 2018, the Serbian NCA rendered at least 155 merger decisions and this number is likely to rise once all clearance decisions are published. As a comparison, during the whole of 2017, the total number of cleared transactions was 139.

Only one merger decision rendered by the Serbian NCA in 2018 was issued after a Phase II investigation. This was the acquisition of a Serbian yeast producer by the French company Lesaffre. ${ }^{18}$

A well-known peculiarity of the Serbian merger control system is that the merger filing thresholds often catch transactions which have little or no effect on the Serbian market. The previous year was no exception - almost half ( $44 \%$, to be more precise) of the cleared mergers were transactions where the target had no turnover in Serbia or such turnover was negligible.

Both equity and asset deals can trigger the merger filing thresholds in the Serbian merger control regime. During 2018, a majority of the cases (126 of them) examined by the Serbian NCA were equity transactions. Apart from the deals which were solely equity or asset, the NCA also dealt with several transactions of mixed nature.

Finally, with respect to the relevant market, as a rule, the Serbian NCA determines the relevant geographic market as national. This was also the case in 2018. Specifically, in almost $90 \%$ of the merger decisions the Serbian NCA rendered during 2018, the relevant geographic market was national. Also, during 2018 the Serbian NCA continued with its approach that the geographic element of the relevant market cannot be wider than Serbia.

\section{Eight new sector inquiries}

To complete its enforcement activities in 2018, the Serbian NCA devoted a lot of its resources to conducting sector inquiries. Specifically, during the

18 Resolution of the Serbian NCA No. 6/0-03-94/2018-6 of 6 February 2018. 
course of the year, the NCA completed as many as eight such analyses in the following sectors: purchase and export of raspberries; software and computer equipment; sportswear and equipment; retail of oil derivatives; tires; food retail (supermarkets); production and sale of cement; baby equipment.

Considering its increased resources compared to the previous period, we can expect a continuation of such market investigations in 2019.

\section{Montenegro}

\section{NCA's jurisdiction extended to State aid}

Perhaps the most important development in competition law in Montenegro during 2018 was the extension of the jurisdiction of the Montenegrin Agency for Protection of Competition (hereinafter: Montenegrin NCA) to State aid matters. ${ }^{19}$ The Montenegrin NCA was previously dealing only with antitrust (restrictive agreements and abuse of dominance) and merger control issues, while State aid matters were the prerogative of a, now abolished, special Commission for the Control of State Aid.

At this moment it is still early to say how this change will affect the practice of the watchdog.

\section{Year of sector inquiries}

While it does not have the power to impose fines, the Montenegrin NCA does have the power to conduct sector inquiries. And it used that prerogative extensively in 2018. Specifically, during 2018 the Montenegrin NCA examined the following markets:

- Distribution of media content and sports channels. The authority performed the analysis based on information obtained from market participants and the relevant sector regulators. Unfortunately, the Montenegrin NCA did not publish its findings, citing the sensitivity of the obtained information. ${ }^{20}$

19 Law on Amendments of the Law on Protection of Competition ('Official Gazette of Montenegro', No. 13/2018).

${ }^{20}$ See news article dated 16 February 2018, available on the website of the Montenegrin NCA at: http://www.azzk.me/novi/joomlanovi/228-obavjestenje-izvjestaj-o-sprovedenoj-analizimaloprodajnog-trzista-distribucije-audio-vizuelnih-medijskih-avm-sadrzaja-i-trzista-distribucijepaketa-sportskih-kanala-i-njihove-dostupnosti-kod-pruzalaca-avm-usluga (26.04.2019). 
- Wholesale and retail of sugar and sunflower oil. The authority sought to establish the relationships between the main competitors on these markets, as well as the vertical relationships between producers, wholesalers, and retailers. During the investigation, the watchdog had turned to undertakings active in the wholesale and retail trade of sugar and sunflower oil, requesting copies of commercial agreements as well as other relevant information. Ultimately, it did not find any foul play. ${ }^{21}$

- Driving schools. The authority also probed driving schools in the Montenegrin town of Nikšić. Specifically, the watchdog was checking reports that driving schools in Nikšić had agreed on the prices for driver training in the town. As a result, the Montenegrin NCA preliminarily established that the driving schools had formally agreed on the prices offered to prospective drivers and launched a formal cartel investigation against the schools. ${ }^{22}$

- Disposal of municipal waste. The authority also took a look at the conditions on the market for waste disposal across the country. During this market investigation, the watchdog assessed how waste disposal companies in Montenegro form their prices. In the end, the market investigation did not indicate any competition law infringements. ${ }^{23}$

\section{Antitrust: two new infringement decisions}

The Montenegrin NCA does not have the power to impose fine for antitrust violations. However, this does not prevent the NCA from rendering infringement decisions, based on which the competent misdemeanor court may later issue a fine.

In 2018, the Montenegrin NCA closed two antitrust cases, both in the area of restrictive agreements.

${ }^{21}$ See news article dated 8 May 2018, available on the website of the Montenegrin NCA at: http://www.azzk.me/novi/joomlanovi/241-obavjestenje-izvjestaj-o-sprovedenim-analizamatrzista-veleprodaje-i-maloprodaje-secera-i-jestivog-suncokretovog-ulja (26.04.2019).

22 See news article dated 8 May 2018, available on the website of the Montenegrin NCA at: http://www.azzk.me/novi/joomlanovi/242-obavjestenje-izvjestaj-o-sprovedenoj-analizi-trzistapruzanja-usluga-obuke-kandidata-za-sve-kategorije-vozila-od-strane-auto-skola-na-teritorijiopstine-niksic (26.04.2019).

23 See news article dated 8 May 2018, available on the website of the Montenegrin NCA at: http://www.azzk.me/novi/joomlanovi/243-obavjestenje-izvjestaj-o-sprovedenom-ispitivanjuuslova-konkurencije-na-trzistu-pruzanja-usluga-odvozenja-i-deponovanja-komunalnog-otpadana-teritoriji-crne-gore (26.04.2019). 
As noted, during a sector inquiry into the driving school market in a Montenegrin town, the watchdog found indications of collusion between the driving schools active in the town. Upon conducting an antitrust investigation, the authority found evidence that the driving schools had indeed agreed on uniform prices for their services, by a written decision adopted by the parties involved. ${ }^{24}$ Such evidence surely made the authority's job of establishing an infringement easier.

In the other infringement decision, the Montenegrin NCA found that an agreement on joint participation in a public procurement procedure concerning medical devices had amounted to a restrictive agreement. Since it does not have the power to impose fines, the watchdog could only declare the joint bid agreement null and void. ${ }^{25}$

\section{Individual exemption: two agreements exempted}

Similarly to Serbia, Montenegro also has a system of individual exemptions of restrictive agreements based on prior notification to the authority. In other words, in the Montenegrin competition law system there is no self-assessment concerning the conditions for individual exemption from the prohibition.

It seems that the undertakings active on the Montenegrin market are not using this procedure extensively, as during 2018 the Montenegrin NCA granted only two individual exemptions. Perhaps this number would rise if the authority later published additional individual exemption decisions; in any case, it should not be expected for the rise to be significant. This situation is the same as last year, when the Montenegrin NCA also granted two individual exemptions (only one of which was partially published).

$\mathrm{Be}$ that as it may, the first individual exemption granted in 2018 concerned a request by three insurance companies active on the Montenegrin market. The exemption pertains to joint participation in a tender organized by the Montenegrin electric power company and was granted for a period of one year. ${ }^{26}$

In the second individual exemption decision, the Montenegrin NCA exempted, for a period of three years, a distribution and promotion agreement between the Dutch company Merck, Sharp and Dohme B.V. and a Montenegrin distributor.

\footnotetext{
24 Resolution of the Montenegrin NCA No. 02-UPI-8/65-18 of 15 October 2018.

25 Resolution of the Montenegrin NCA No. 02-UPI-11/129-16 of 23 March 2018.

26 Resolution of the Montenegrin NCA No. 02-UPI-59/10-18 of 12 November 2018.
} 


\section{Merger control: another year of Phase I clearances}

Similarly to Serbia, Montenegrin competition law also contains very low merger filing thresholds, which catch even transactions which have no connection with the Montenegrin market. As a result, the largest part of the authority's workload pertains to merger control.

As described, in the previous year the Montenegrin NCA rendered only two antitrust infringement decisions. On the other hand, it issued at least 44 new merger decisions - and this number may still rise once all merger decisions from 2018 are published. All 2018 merger decisions were unconditional Phase I clearances.

\section{Bosnia and Herzegovina}

\section{A new way of calculating merger filing fees}

During 2018 there were no significant legislative changes in Bosnian competition law. The only notable novelty is a change in how the merger filing fees are calculated in this jurisdiction.

Earlier, the merger filing fee was always determined in a fixed amount. Specifically, the total fee for a Phase I clearance was approx. EUR 2,250. On the other hand, if the Bosnian NCA would have cleared a transaction only after Phase II, the total fee would have been approx. EUR 13,500.

After the latest changes, ${ }^{27}$ the total fee for a Phase I clearance has been raised to approx. EUR 3,500. This is still significantly less than, for example, Serbia, where the standard fee for a Phase I clearance is EUR 25,000.

As for the fee for a Phase II clearance, there is no longer a fixed fee - the amount is now linked to the turnover of the parties.

\section{2. 'Ethnic veto' in competition law enforcement again in application}

The competition law of Bosnia and Herzegovina includes what could be characterized as an 'ethnic veto' in competition law enforcement (Gajin, 2018, p. 295). Specifically, due to the way in which the country's competition

27 Decision on the amendment of the Decision on administrative fees in relation to the procedural actions before the Competition Council of Bosnia and Herzegovina, 'Official Gazette of Bosnia and Herzegovina', nos. 30/06, 18/11, and 75/18. 
authority - Competition Council (hereinafter: Bosnian NCA) is set up, and also considering the deliberation procedure within the authority, each of the three 'constituent peoples' (Croats, Bosniaks, Serbs) could effectively block the work of the competition authority. At least two such instances occurred in $2017^{28}$ and the trend continued in 2018.

According to the information available on the website of the Bosnian NCA, during 2018 the watchdog failed to reach a decision due to the use of the "ethnic veto' on at least four occasions. Concretely, the authority had to abandon the enforcement of one of its decisions, could not decide on a notified concentration, and could not adopt two official opinions since the support of the representatives of all three 'constituent peoples' was lacking.

\section{High level of antitrust enforcement continues}

Compared to the other Balkan jurisdictions, in which merger control dominates the enforcement agenda, competition law enforcement in Bosnia and Herzegovina is characterized by an emphasis on antitrust. On the one hand, this is due to the procedural rules in Bosnia and Herzegovina, which allow complainants to be a party in antitrust proceedings, and, on the other, due to relatively high merger filing thresholds in this jurisdiction.

This high level of antitrust enforcement is, however, mainly reflected in a higher number of cases, not in a higher number of infringement decisions.

According to preliminary data, during 2018 the Bosnian NCA established abuse of dominance in two cases and found an infringement in the form of restrictive agreements in another two instances. Contrast that with the number of incoming cases: three in the area of restrictive agreements and 11 in the area of abuse of dominance.

Apart from finding an infringement, the Bosnian NCA also has the power to impose fines, in the amount of up to $10 \%$ of the infringing undertaking's annual turnover. In 2018, the NCA imposed fines in the total amount of approx. EUR 300,000. In addition, the authority also collected approx. EUR 100,000 in administrative fees. The proceeds from both belong to the country's budget.

\section{Individual exemption: one agreement given antitrust clearance}

Same as the competition laws of Serbia and Montenegro, respectively, the competition law of Bosnia and Herzegovina also has a system of individual

28 Ibidem. 
exemptions from prohibition based on prior notification to the competition authority.

During 2018, the Bosnian NCA individually exempted one notified agreement. The agreement was only cleared following an in-depth investigation.

\section{Merger control: An unusually busy year}

Due to the relatively high merger filing thresholds in Bosnia and Herzegovina, merger filings in this jurisdiction are not as common as in some of the other Balkan jurisdictions. In this context, 2018 can be characterized as fairly busy for the Bosnian NCA in the area of merger control.

Specifically, the Bosnian NCA received 35 merger notifications - 24 transactions were cleared in Phase I, in one case the NCA could not decide on the notified transaction due to the 'ethnic veto', and the remaining 10 cases remained pending at the end of the year. ${ }^{29}$ With respect to the cleared transactions, only one was given the green light after a Phase II probe, while all others were cleared in Phase I.

Also notable about competition law enforcement in Bosnia and Herzegovina is a relatively high number of dismissed merger filings. Precisely, in 2018 the Bosnian NCA dismissed at least 11 transactions. From a practical point of view, this is because one of the merger filing thresholds in the Bosnian Competition Act refers to market share and the parties are not always sure in advance whether their transaction is notifiable or not.

6. Three sector inquiries conducted

Apart from its antitrust and merger control activities, the Bosnian NCA also conducted three sector inquiries: in the oil and oil derivates, taxi transportation, and water supply sectors, respectively. The oil and oil derivates sector was examined on the national level, taxi transportation in the Sarajevo Canton, and water supply was looked at in the largest cities in Bosnia and Herzegovina.

\section{Amendments to the Competition Act coming up?}

In its plan of activities for $2019,{ }^{30}$ the Bosnian NCA inter alia noted how it intends to initiate the procedure of amendments of the Competition Act with

29 Annual report of the Competition Council of Bosnia and Herzegovina for 2018, Document no. 01-50-1-395-11/19 of 4 March 2019.

30 Work programme of the Competition Council of Bosnia and Herzegovina for 2019, Document no. 01-02-3-390-9/18 of 31 January 2019. Available on the website of the Bosnian NCA at: http://bihkonk.gov.ba/datoteka/1056_001.pdf (26.04.2019). 
the Ministry of External Trade and Economic Relations. Since this is not the first time that changes in competition law have been announced, we can only wait and see whether they will actually come to fruition this year.

\section{North Macedonia}

\section{New Competition Commission appointed}

The biggest news from Macedonia is that the country has changed its name to North Macedonia.

In the area of competition law, the highlight is that the country's competition authority - Commission for Protection of Competition (hereinafter: North Macedonian NCA) - has a new President and four other members of the authority's governing body. The appointees are:

- Vladimir Naumovski (President);

- Dimitrija Vrevezoski (a member of the Commission and the head of the body which imposes fines for competition law infringements);

- Naser Zharku (a member of the Commission);

- Aleksandar Davchevski (a member of the Commission); and

- Ana Vitkova (a member of the Commission).

According to the North Macedonian Competition Act, the mandate of the President and members of the Commission is five years, with the possibility of re-appointment. ${ }^{31}$

\section{Focus on merger control}

As was also the case last year, during 2018 the focus of the North Macedonian NCA was on merger control. This is no wonder, considering the very low merger filing thresholds in Macedonian competition law.

According to information published on the website of the North Macedonian NCA, during 2018 the authority received as many as 57 new merger notifications. Based on the watchdog's previous practice, it can be reasonably expected that their vast majority, if not all of the notified transactions, will be cleared in Phase I. As a comparison, based on unofficial data, during 2017 the North Macedonian NCA dealt with 44 transactions in total.

${ }^{31}$ Law on Protection of Competition, 'Official Gazette of the Republic of North Macedonia', issues 36/11, 41/14, 53/16, and 83/18, Article 27, para. 1 . 
Due to the way the merger filing thresholds are set, a majority of transactions notified to the North Macedonian NCA have little or no connection with the North Macedonian market. However, if it's any consolation, the merger filing fee is at least much lower than in Serbia or Montenegro: it amounts to approx. EUR 600.

\section{All is quiet on the antitrust front}

And while there were a plenty of decisions in the merger control sphere, North Macedonian competition law had a quiet year on the antitrust front, with no reported new cases.

What probably contributes to lessening the NCA's workload in the area of antitrust is the fact that, unlike in the other Balkan jurisdictions, in North Macedonian individual exemptions of restrictive agreements are governed by self-assessment. Naturally, the North Macedonian NCA did not render any individual exemption decisions in 2018.

\section{State aid}

Apart from antitrust (restrictive agreements and abuse of dominance) and merger control matters, the North Macedonian NCA is also in charge of State aid. However, the most recent State aid decision available on the authority's website dates back from 2016. Based on this, State aid is not a priority in the NCA's enforcement activities.

\section{Literature}

Gajin, D. (2018). What's New in Western Balkans. YARS 2018, 11(8), p. 285-296, http:// doi.org/ 10.7172/1689-9024.YARS.2018.11.18.11

Kojovic, T. and Gajin, D. (2012). Vertical Restraints under Serbian Competition Law: A Comparison with EU Law. European Competition Law Review 33(8), p. 357-366.

Kojovic, T. and Gajin, D. (2017). Competition Law in Serbia. The Netherlands: Wolters Kluwer. 